HARZBURGITE NODULES FROM A LAMPROPHYRE NEAR WAWA, ONTARIO, CANADA

A.J.A. Janse (Selco Mining Corporation Limited, 55 Yonge Street, Toronto, Ontario M5E lJ4, Canada)

General

Composite lamprophyre dykes are exposed along highway 17 in a road cut 5 miles south of Wawa. There are three parallel dykes, two of which are approximately three feet wide and one is approximately nine feet wide. The dykes are intruded into a small stock of granodiorite and they have a vertical dip and a strike of $\mathrm{N} 240^{\circ} \mathrm{E}$. The dyke rocks are rich in well preserved olivine and phlogopite phenocrysts which are embedded in a groundmass of serpentine, phlogopite and calcite, which also contains small, scattered, euhedral opaque crystals which are predominantly spinels of various composition. The widest dyke contains multiple intrusions of several varieties of lamprophyre rich in olivine phenocrysts or rich in mica. The olivine rich variety contains locally several fist-size harzburgite nodules.

\title{
Mineralogy of the nodules
}

The harzburgite nodules are composed of olivine with minor amounts of orthopyroxene and chromite. There is a beginning of serpentinization in the numerous cracks which penetrate the olivine crystals and there is little development of phlogopite. The orthopyroxene is slightly more altered than the olivine. The texture of the olivine is anhedral and granular with mortar texture and undulose extinction in places along the margin of the nodules. The forsterite content of the large unstrained olivines, the mortared olivine and the undulose olivines varies from 87.7 to 89.3 percent, while the enstatite content of the orthopyroxene varies from 88.3 to 90.0 percent. Electron probe analyses on several grains indicated that there is no iron enrichment in the olivines towards the margin of the nodules. The opaques consist of magnesian chromite (No. 3

Table 1).

Mineralogy of the lamprophyres

The olivine phenocrysts of the lamprophyre are euhedral to subhedral and they are more altered than the olivines in the nodules. Their forsterite content has a larger spread and varies from 63.0 to 80.2 percent. The phlogopites of the lamprophyre are of two types: one type consists of large poikilitic unzoned subhedral crystals, while the other type consists of euhedral zoned phenocrysts which contains amounts of up to 4\% titania (No. 4 Table 1). The opaque minerals in the lamprophyre are predominantly chromium and titanium rich spinels of compositions varying between chrome spinel, titaniferous chromepoor spinel, titaniferous chrome-rich spinel, ilmenite and titaniferous magnetite. 
Concluding remarks

Because garnet has not been found in the lamprophyre and the magnesian content of the ilmenite is relatively low (approximately 3\%) the lamprophyre cannot be classified as a kimberlitic rock. The lack of clinopyroxenes in the rock precludes the determination of its place on the temperature-depth curve, but the mineralogy of the nodules still indicates that the rock has a deep seated origin. The presence of harzburgite nodules in this lamprophyre indicates that the deep reaching fault and fracture system of the Kapuskasing structure probably taps the Upper Mantle. Thus lamprophyres or other rocks containing nodules of deep seated origin may be found in other areas traversed by the Kapuskasing faults.

'iable 1. Compositions of selected minerals from the Wawa dykes

\begin{tabular}{|c|c|c|c|c|c|c|c|c|}
\hline Wt? & 1 & 2 & 3 & 4 & 5 & 6 & 7 & 8 \\
\hline$\overline{\mathrm{SiO}_{2}}$ & 41.81 & 57.96 & 0.74 & 38.17 & 40.30 & 0.46 & 0.25 & 0.46 \\
\hline $\mathrm{TiO}_{2}$ & 0.01 & 0.00 & 0.29 & 3.90 & 0.04 & 50.42 & 13.55 & 5.36 \\
\hline $\mathrm{Al}_{2} \mathrm{O}_{3}$ & 0.02 & 1.26 & 1.51 & 15.04 & 0.07 & 0.05 & 5.13 & 10.79 \\
\hline $\mathrm{Cr}_{2} \mathrm{O}_{3}$ & 0.02 & 0.12 & 64.35 & 0.03 & 0.11 & 0.02 & 2.87 & 33.50 \\
\hline$F e \overline{0}$ & 6.68 & 4.33 & 20.99 & 7.48 & 12.61 & 41.15 & 70.90 & 38.35 \\
\hline $\mathrm{Mg} 0$ & 50.97 & 35.73 & 10.61 & 20.93 & 46.15 & 2.83 & 5.17 & 10.21 \\
\hline $\mathrm{CaO}$ & 0.03 & 0.21 & 0.09 & 0.00 & 0.23 & 0.43 & 0.16 & 0.05 \\
\hline MnO & 0.08 & 0.10 & 0.47 & 0.11 & 0.19 & 2.24 & 0.94 & 0.31 \\
\hline $\mathrm{Na}_{2} \mathrm{O}$ & 0.05 & 0.11 & 0.01 & 0.45 & 0.01 & 0.11 & 0.00 & 0.18 \\
\hline $\mathrm{K}_{2} \mathrm{O}$ & 0.00 & 0.13 & 0.08 & 9.15 & 0.00 & 0.00 & 0.00 & 0.00 \\
\hline $\mathrm{NiO}$ & 0.32 & 0.05 & 0.09 & 0.00 & 0.29 & 0.00 & 0.04 & 0.05 \\
\hline Total & 99.99 & 100.00 & 99.24 & 95.27 & 100.00 & 97.72 & 99.01 & 99.25 \\
\hline
\end{tabular}

Table 2. Structural formulae

\begin{tabular}{l|r|r|r|r|r|r|r|r|}
\hline & $4(0)$ & $6(0)$ & $12(0)$ & $24(0)$ & $4(0)$ & $3(0)$ & $16(0)$ & $12(0)$ \\
\hline $\mathrm{Si}$ & 1010 & 1946 & 78 & 5998 & 998 & 11 & 37 & 45 \\
$\mathrm{Ti}$ & 0 & 0 & 23 & 461 & 0 & 964 & 1607 & 417 \\
$\mathrm{Al}$ & 0 & 50 & 188 & 2784 & 1 & 1 & 954 & 1318 \\
$\mathrm{Cr}$ & 0 & 6 & 5313 & 0 & 1 & 0 & 356 & 2746 \\
$\mathrm{Fe}$ & 135 & 124 & 1832 & 982 & 263 & 875 & 9357 & 3327 \\
$\mathrm{Mg}$ & 1834 & 1818 & 1652 & 4900 & 1717 & 106 & 1213 & 1577 \\
$\mathrm{Ca}$ & 0 & 9 & 12 & 0 & 5 & 11 & 23 & 3 \\
$\mathrm{Mn}$ & 1 & 4 & 43 & 14 & 3 & 47 & 125 & 24 \\
$\mathrm{Na}$ & 3 & 7 & 0 & 133 & 0 & 5 & 0 & 33 \\
$\mathrm{~K}$ & 0 & 6 & 12 & 1830 & 0 & 0 & 0 & 0 \\
$\mathrm{Ni}$ & 6 & 0 & 0 & 0 & 5 & 0 & 0 & 3 \\
\hline Total & 2989 & 3970 & 9160 & 17102 & 2993 & 2021 & 13672 & 9493 \\
\hline
\end{tabular}

FO응

En\%

$\mathrm{Cr} / \mathrm{Cr} \mathrm{Al}$
88 89 0.96
76 
Probe analyses through Dr H.A.O. Meyer, Purdue University - 1: olivine from harzburgite, average of 10 analyses, calculated anhydrous, 2: orthopyroxene from harzburgite, average 6 analyses anhydrous, 3: chromite from harzburgite, 1 analyses, 4: phlogopite from lamprophyre, 1 analyses, 5: olivine from lamprophyre, average of 5 analyses, anhydrous, 6: ilmenite from lamprophyre, 1 analyses, 7: titaniferous magnetite, 1 analyses, 8: titaniferous chromespinel, 1 analyses. 